JPdK Volume 2 No 2 Tahun 2020 Halaman 161-167 JURNAL PENDIDIKAN dan KONSELING

\title{
Peningkatan Keterampilan Proses Sains IPA dengan Menggunakan Metode Ekperimen Di Sekolah Dasar
}

\author{
Soni Bernadus Masus ${ }^{1}$, Fadhilaturrahmi ${ }^{2}$ \\ Pendidikan Guru Sekolah Dasar \\ Fakultas Ilmu Pendidikan \\ Universitas Pahlawan Tuanku Tambusai \\ Email: sonybernadus88@gmail.com
}

\begin{abstract}
Abstrak
Latar belakang penelitian ini adalah rendahnya keterampilan proses sains IPA pada siswa kelas III SD Pelangi School Kecamatan Batam Kota. Tujuan penelitian adalah untuk mendapatkan gambaran perencanaan pembelajaran keterampilan proses sains IPA, pelaksanaan pembelajaran keterampilan proses sains IPA dan peningkatan keterampilan proses sains IPA dengan menggunakan metode eksperimen. Jenis penelitian yang digunakan adalah Penelitian Tindakan Kelas (PTK). Desain penelitian menggunakan model penelitian Kemmis dan Mc Taggart dan dalam setiap siklus terdiri dari empat tahap yaitu perencanaan, pelaksanaan, pengamatan dan refleksi. Penelitian dilaksanakan sebanyak dua siklus dan setiap siklus terdiri dari satu pertemuan. Alat pengumpul data berupa lembar observasi dan lembar kerja siswa. Teknik analisis data menggunakan teknik analisis kualitatif dan kuantitatif. Hasil penelitian pada siklus I dengan persentase 69,23\% dengan kategori cukup, dan pada siklus II meningkat menjadi $84,61 \%$ dengan kategori baik. Dengan demikian, dengan menggunakan metode eksperimen dapat meningkatkan keterampilan proses sains IPA.
\end{abstract}

Kata Kunci: Keterampilan Proses Sains IPA, Metode Eksperimen

\begin{abstract}
The background of this research is the low science process skills of IPA in grade III students of SD Pelangi School Batam Kota Sub-District. The purpose of the research is to get an overview of science science process science learning planning, the implementation of science science process science skills and the improvement of science process science skills by using experimental methods. The type of research used is Class Action Research (PTK). The research design uses the Kemmis and Mc Taggart research models and in each cycle consists of four stages namely planning, implementation, observation and reflection. Research is conducted as many as two cycles and each cycle consists of one meeting. Data collection tools in the form of observation sheets and student worksheets. Data analysis techniques use qualitative and quantitative analysis techniques. The results of the study on cycle I with a percentage of $69.23 \%$ with enough category, and in cycle II increased to $84.61 \%$ with good category. Thus, using experimental methods can improve the science process skills of IPA.
\end{abstract}

Keywords: Science Process Skills, Experimental Methods 


\section{PENDAHULUAN}

Pendidikan sangat penting dalam kehidupan umat manusia dan tidak dapat dipisahkan dari kehidupan itu sendiri. Sifatnya mutlak dalam kehidupan, baik dalam kehidupan seseorang, keluarga bangsa dan negara. Menurut Undang-Undang No.20 Tahun 2003 tentang Sistem Pendidikan Nasional menyatakan bahwa Pendidikan adalah usaha sadar dan terencana untuk mewujudkan suasana belajar dan proses pembelajaran agar peserta didik secara aktif mengembangkan potensi dirinya untuk memiliki kekuatan spiritual keagamaan, akhlak mulia, serta keterampilan yang diperlukan dirinya, masyarakat, bangsa dan Negara. Berdasarkan undang-undang tersebut, dapat dipahami bahwa pendidikan ditujukan untuk mengembangkan potensi-potensi peserta didik serta keterampilan yang digunakan dalam menjalani hidup di masyarakat, bangsa dan negara.

Salah satu mata pelajaran yang diajarkan di SD yang dapat mengembangkan kepribadian siswa adalah mata pelajaran Ilmu Pengetahuan Alam (IPA). Menurut Sudrajat (dalam Pebriana, PH, dkk, 2019:104) bahwa salah satu tujuan mata pelajaran IPA di SD yang harus dikembangkan adalah keterampilan proses. Pembelajaran IPA di SD hendaknya lebih menekankan kepada pemikiran kecakapan proses dibanding dengan penguasaan materi IPA, karena kecakapan proses ini merupakan kecakapan prasyarat yang harus dimiliki siswa agar dapat mempelajari bidang studi lainnya sesuai dengan minatnya.

Menurut Hamalik (dalam Juhji, 2016:61) mengemukakan bahwa pengertian keterampilan proses dalam bidang ilmu pengetahuan alam adalah pengetahuan tentang konsep-konsep dalam prinsip-prinsip yang dapat diperoleh peserta didik bila dia memiliki kemampuankemampuan dasar tertentu yaitu keterampilan proses sains yang dibutuhkan untuk menggunakan sains.

Kajian Ilmu Pengetahuan Alam yang dimaksud berhubungan dengan cara mencari tahu tentang alam secara sistematis, sehingga IPA bukan hanya penguasaan kumpulan pengetahuan yang berupa fakta-fakta, konsepkonsep atau prinsip-prinsip saja tetapi juga merupakan suatu proses penemuan. Proses pembelajarannya menekankan pada pemberian pengalaman secara langsung untuk mengembangkan kompetensi agar menjelajahi dan memahami alam sekitar secara ilmiah. Akan tetapi kenyataannya sangat berlainan. Hal ini dimungkinkan karena salah satu penyebabnya adalah penggunaan metode atau pendekatan pembelajaran yang kurang tepat oleh guru dalam mengajar. Guru lebih banyak mengajarkan konsep-konsep materi melalui transfer ilmu pengetahuan dan pemberian contoh yang cenderung menjadi bahan hafalan bagi siswa sehingga menciptakan suasana belajar yang monoton dan membosankan.

Pembelajaran IPA tidak hanya menyampaikan informasi dan pemahaman materi saja, namun juga harus memperhatikan pengembangan kemampuan yang lainnya seperti kemampuan mengamati suatu objek, menggunakan alat dan bahan, melakukan percobaan, kemampuan mengkomunikasikan dan kemampuan siswa dalam menyimpulkan hasil pengamatan atau percobaan (Samatowa, 2011:94).

Salah satu metode yang melibatkan keaktifan siswa untuk meningkatkan keterampilan proses sains adalah metode eksperimen. Penerapan metode eksperimen sangat membantu siswa dalam proses pembelajaran mereka karena dengan metode ini siswa diberikan kesempatan untuk mengalami sendiri atau melakukan sendiri dalam proses pembelajaran tertentu. Menurut Sagala (dalam Agustiningsih, 2014:28) metode eksperimen dalam pembelajaran adalah cara penyajian bahan pelajaran yang memungkinkan siswa melakukan 
percobaan untuk membuktikan sendiri suatu pertanyaan atau hipotesis yang dipelajari. Dari pemaparan tersebut dapat disimpulkan bahwa metode eksperimen melibatkan aktivitas siswa secara langsung, siswa diberikan kesempatan untuk melakukan percobaan untuk menemukan sendiri fakta-fakta maupun konsep-konsep dalam pembelajaran.

Berdasarkan observasi di kelas III SD Pelangi School Kecamatan Batam Kota, terlihat aktivitas keterampilan proses sains belum muncul. Hal ini dikarenakan beberapa faktor, diantaranya pembelajaran masih didominasi oleh guru, kurangnya fasilitas dan media/alat peraga yang dibutuhkan dalam pembelajaran, kurangnya minat belajar siswa sehingga aktivitas keterampilan proses sains belum optimal, beberapa siswa masih belum melakukan pengamatan dengan menggunakan panca indra yang sesuai, menggunakan alat dan bahan percobaan tidak sesuai dengan fungsi, kurang teliti dalam melakukan percobaan meskipun sudah dijelaskan guru pada awal pembelajaran, belum aktif mengkomunikasikan hasil percobaan dan belum dapat menyusun kesimpulan sesuai dengan hasil yang didapatkan.

\section{METODOLOGI PENELITIAN}

Metode penelitian ini menggunakan metode Penelitian Tindakan Kelas (PTK). Menurut Mulyani (2015: 48) penelitian tindakan kelas adalah penelitian tindakan yang dilakukan di dalam kelas ketika proses pembelajaran berlangsung. Selanjutnya dijelaskan oleh Suhardjono (dalam NurAeni, dkk, 2017:625) PTK merupakan penelitian yang dilakukan oleh guru bekerjasama dengan peneliti lain atau bahkan bisa saja guru kelasnya yang menjadi peneliti di kelas untuk meningkatkan mutu pembelajaran.

Model penelitian ini menggunakan model Kemmis dan Mc Taggart (dalam Kolin, 2014:159) terdiri dari empat sub kegiatan, yakni perencanaan (plan), pelaksanaan tindakan (action), observasi (observation), dan refleksi (reflection) yang saling berkaitan satu sama lainnya.

Instrumen yang digunakan dalam penelitian ini adalah berupa: rencana pelaksanaan pembelajaran, tes, lembar kerja siswa dan lembar observasi. Dalam Rencana Pelaksanaan Pembelajaran (RPP) peneliti menggunakan acuan utama pembelajaran penggunaan prosedur metode eksperimen, yakni tahap persiapan eksperimen, tahap pelaksanaan eksperimen dan tahap tindak lanjut eksperimen.

Tes yang digunakan berupa soal esai yang memuat beberapa indikator keterampilan proses sains siswa yang meliputi: 1) mengamati, 2) menggunakan alat dan bahan 3) melakukan percobaan mengkomunikasikan/mengajukan pertanyaan 5) menyimpulkan hasil percobaan.

Lembar Kerja Siswa (LKS) yang dimaksud dalam penelitian ini adalah bahan ajar yang berisi langkah-langkah pelaksanaan pembelajaran yang harus dikerjakan oleh siswa yang mengacu pada kompetensi dasar yang harus dicapai. Lembar Kerja Siswa tersebut mengukur aspek keterampilan proses sains mulai dari kegiatan belajar mengajar hingga kegiatan siswa melakukan percobaan.

Lembar Observasi dalam penelitian ini mengandung 4 kategori alternative tanggapan terhadap suatu pertanyaan. Observasi yang dilakukan terhadap siswa dimulai dari awal kegiatan belajar mengajar hingga 
siswa melakukan percobaan yang meliputi: 1) pengamatan, 2) menggunakan alat dan bahan, 3) melakukan percobaan, mengkomunikasikan/mengajukan pertanyaan, 5) menyimpulkan Waktu penelitian pada bulan februari 2020 bertempat di SD Pelangi School Kecamatan Batam Kota. Subjek dalam penelitian ini adalah siswa kelas III SD Pelangi School yang berjumlah 14 siswa. Pelaksanaan tindakan dimulai dengan siklus I, yang terdiri dari 4 tahapan kegiatan yaitu:

1) Perencanaan (Planning), kegiatan ini peneliti menyiapkan silabus pembelajaran, Rencana Pelaksanaan Pembelajaran (RPP), Lembar Kerja Siswa (LKS), lembar observasi aktivitas siswa dan lembar observasi aktivitas guru.

2) Pelaksanaan (action), pada tahap ini peneliti melaksanakan tindakan sesuai dengan langkah-langkah pembelajaran yang telah direncanakan dalam RPP.

3)Pengamatan (observation), pengamatan dilakukan bersamaan dengan pelaksanaan tindakan. Observer I melakukan pengamatan terhadap aktivitas siswa dan observer II mengamati aktivitas guru.

4) Refleksi (reflection), peneliti bersama observer mendiskusikan kendala-kendala pada saat proses pembelajaran baik guru/peneliti maupun kendala yang dialami siswa.

Teknik pengumpulan data yang digunakan yaitu lebar observasi dan dokumentasi, sedangkan instrumen pengumpulan data terdiri dari instrumen perangkat pembelajaran seperti RPP dan LKS dan instrumen penelitian yang digunakan berupa lembar observasi keterampilan proses sains siswa yang disusun untuk mengetahui peningkatan persentase keterampilan proses sains siswa dari aspek mengamati, menggunakan alat dan bahan, melakukan percobaan,

mengkomunikasikan/mengajukan pertanyaan dan menyimpulkan hasil percobaan. Sedangkan lembar observasi aktivitas siswa dan lembar observasi aktivitas guru disusun untuk mengetahui keterlaksanaan proses pembelajaran dengan menggunakan metode eksperimen yang telah disusun dalam RPP.

Teknik analisis data keterampilan proses sains pada tiap siklus menggunakan

rumus Trianto (dalam Siregar, 2017:21), yaitu:

$$
\mathrm{KB}=\underset{T t}{\mathrm{~T}} \times 100 \% .
$$

Hasil perhitungan ketuntasan Keterampilan Proses Sains masingmasing siswa kemudian dikategorikan sesuai dengan tabel berikut ini:

\begin{tabular}{|c|c|c|c|}
\hline \multicolumn{4}{|c|}{ Proses Sains Siswa } \\
\hline Jo & Kategori & hlah Skor & Nilai \\
\hline 1 & k Sekali (4) & $16-20$ & $6-100$ \\
\hline 2 & (3) & $11-15$ & 6-85 \\
\hline 3 & up (2) & $6-10$ & $0-75$ \\
\hline 4 & $\begin{array}{c}\text { Kurang } \\
\text { (1) }\end{array}$ & $<54$ & $<54$ \\
\hline
\end{tabular}

Tabel 1.Kualifikasi Keterampilan

Sudjana (dalam Siregar, 2017:21).

Selanjutnya Untuk mengetahui ketuntasan klasikal dikatakan tercapai apabila $80 \%$ dari seluruh siswa memahami materi yang telah dipelajari. Untuk menganalisis persentase ketuntasan belajar secara klasikal dirumuskan sebagai berikut :

$\mathbf{P}=\underline{\Sigma}$ siswa yang tuntas belajar $100 \%$ Esiswa

(Zainal Aqib (dalam Siregar 2017:21) 


\section{HASIL PENELITIAN DAN PEMBAHASAN}

\section{A. Deskripsi Tindakan Tiap Siklus}

Tindakan yang dilakukan pada penelitian ini adalah pelaksanaan pembelajaran dengan penerapan metode eksperimen terhadap siswa kelas III SD Pelangi School Kecamatan Batam Kota. Penelitian ini dilakukan dalam 2 siklus pada mata pelajaran IPA. Siklus I terdiri dari 1 pertemuan dan siklus II terdiri dari 1 kali pertemuan pada tema energi dan perubahannya. Proses pembelajaran dilakukan dengan menggunakan metode eksperimen. Pada pertemuan di setiap siklus observer mengamati aktivitas guru dan siswa menggunakan lembar observasi yang telah disiapkan peneliti.

\section{Deskripsi Hasil Tindakan Siklus I}

Pada siklus I terdiri dari dua pertemuan dengan menyajikan materi di setiap pertemuan dan pemberian LKS di setiap siklus.

\section{a. Tahap Perencanaan Siklus I}

Tahap perencanaan ini peneliti telah menyiapkan silabus dan RPP. Adapun langkahlangkah pembelajaran dengan metode eksperimen yang terdiri dari 3 tahap, yaitu: 1) tahap persiapan eksperimen, 2) tahap indikator keberhasilan penelitian yaitu $80 \%$ maka perlu dilakukan perbaikan pada siklus II. Perbaikan-perbaikan tersebut meliputi 1) perlu dijelaskan kepada siswa tentang tujuan eksperimen, agar siswa memahami masalah yang harus dibuktikan melalui eksperimen, 2) memberikan penjelasan terhadap siswa tentang alat dan bahan yang digunakan dalam eksperimen, 3) selama eksperimen pelaksanaan eksperimen, 3) tahap tindak lanjut eksperimen.

Pada tahap ini peneliti juga menyusun instrumen penelitian berupa instrumen pengumpulan data, yaitu lembar observasi aktivitas guru, lembar observasi aktivitas siswa dan Lembar Kerja Siswa. Selanjutnya peneliti juga meminta kesediaan guru kelas III SD Pelangi School, ibu Sondang $\mathrm{H}$. Simbolon sebagai observer I untuk mengamati aktivitas siswa dan ibu Riris M. Gultom sebagai observer II untuk mengamati aktivitas guru dan peneliti bertindak sebagai guru di kelas III SD Pelangi School Kecamatan Batam Kota. B. Perbandingan Hasil Tindakan Tiap Siklus

Hasil keterampilan proses sains IPA pada siklus I hanya mencapai $69,23 \%$ dengan kategori "cukup" yaitu berada pada rentang 60\%-75\%. Keterampilan proses sains IPA pada siklus I belum mencapai ketuntasan klasikal $80 \%$. Merujuk pada persentase ketercapaian pelaksanaan pembelajaran keterampilan proses sains $(69,23 \%)$ dari berlangsung guru harus mengamati pekerjaan siswa, membimbing jalannya eksperimen, 4) setelah eksperimen selesai guru dan siswa mendiskusikan hasil eksperimen dan mengevaluasi dengan tes atau tanya jawab. Rekapitulasi keterampilan proses sains IPA pada siklus I dan II dapat dilihat pada tabel berikut ini:

Tabel 2. Rekapitulasi Keterampilan Proses Sains IPA

Siklus I dan Siklus II

\begin{tabular}{|c|l|l|l|l|l|}
\hline \multirow{2}{*}{ Skor } & \multirow{2}{*}{ Kategori } & \multicolumn{2}{c|}{ Siklus I } & \multicolumn{2}{c|}{ Siklus II } \\
\cline { 3 - 6 } & & Tuntas & dak Tuntas & Tuntas & ak Tuntas \\
\hline $86 \%-100 \%$ & Baik sekali & 2 siswa & - & 7 siswa & - \\
\hline $76 \%-85 \%$ & Baik & 7 siswa & - & 4 siswa & - \\
\hline $60 \%-75 \%$ & Cukup & - & 2 & - & 1 siswa \\
\hline$>54 \%$ & Kurang & - & 2 & - & 1 siswa \\
\hline \multicolumn{2}{|c|}{ Jumlah } & $\mathbf{9}$ siswa & 4 siswa & $\mathbf{1}$ siswa & 2 siswa \\
\hline \multicolumn{2}{|c|}{ Presentase } & $\mathbf{6 9 , 2 3 \%}$ & $\mathbf{3 0 , 7 6 \%}$ & $\mathbf{3 4 , 6 1 \%}$ & $\mathbf{1 5 , 3 8 \%}$ \\
\hline egori & Cukup & Kurang & Baik & ang \\
\hline
\end{tabular}


Setelah dilakukan perbaikan, pada siklus II mengalami peningkatan persentase dari pada siklus sebelumnya (siklus I), keterampilan proses sains siswa terjadi peningkatan $15,38 \%$ menjadi $84,61 \%$ dengan kategori baik. Karena pada siklus II sudah mencapai indikator keberhasilan yang diharapkan yaitu hasil persentase secara keseluruhan mencapai
$>80 \%$ maka pembelajaran keterampilan proses sains dengan metode eksperimen dapat dihentikan pada siklus II. Persentase keterampilan proses sains IPA pada siklus I dan Siklus II juga dapat dilihat pada grafik berikut:

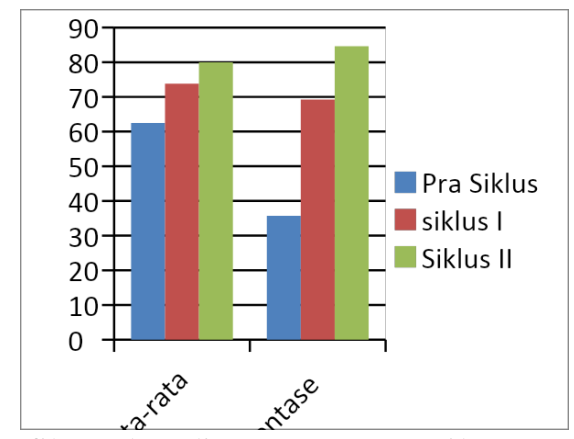

Gambar 1 Grafik Perbandingan Keterampilan Proses Sains IPA Siklus I dan Siklus II

Setelah melihat rekapitulasi keterampilan proses sains IPA pada grafik di atas, dapat dilihat bahwa adanya peningkatan keterampilan proses sains IPA dari siklus I hingga siklus II. Dapat diketahui bahwa pelaksanaan keterampilan proses sains siklus II $84,61 \%$ sudah mencapai indikator yang telah ditetapkan yaitu $80 \%$ dengan kategori baik. Dengan hal ini menunjukan bahwa tahapan pembelajaran keterampilan proses sains IPA sudah berjalan sesuai dengan tahapan pembelajaran metode eksperimen.

Siswa kelas III SD Pelangi School

Kecamatan Batam Kota mendapatkan pengalaman belajar secara langsung selama proses pembelajaran, demikian juga dengan kemampuan siswa lebih terasa. Hal ini sesuai dengan pendapat Agustiningsih (2014:49) bahwa penggunaan metode eksperimen dalam prosesnya mengutamakan aktivitas siswa sehingga peran guru cenderung lebih banyak sebagai pembimbing dan motivator. Oleh karena itu, pembelajaran dengan metode eksperimen siswa diberikan kesempatan untuk mengalami langsung, diberikan kesempatan untuk melakukan percobaan, mengamati prosesnya hingga menemukan sendiri jawabannya agar pengalaman siswa lebih bermakna.
Hasil perolehan keterampilan proses sains IPA pada siklus II mengalami peningkatan dibandingkan siklus I. Secara keseluruhan persentase ketuntasan sebesar 84,61\%. Hasil keterampilan proses sains telah mencapai indikator keberhasilan $80 \%$ dengan kategori baik. Dengan demikian dapat disimpulkan bahwa keterampilan proses sains IPA mengalami peningkatan dengan menggunakan metode eksperimen. Jadi, hasil penelitian ini mendukung hipotesis yang diajukan yaitu "jika metode Eksperimen diterapkan maka dapat Meningkatkan Keterampilan Proses Sains IPA Siswa Kelas III SD Pelangi Batam Kota”.

\section{SIMPULAN}

Berdasarkan hasil penelitian yang dilakukan, pelaksanaan pembelajaran Keterampilan Proses Sains IPA siswa kelas III SD Pelangi School Kecamatan Batam Kota dapat dilaksanakan melalui 2 tahap, yaitu sebagai berikut:

1.Tahap perencanaan pembelajaran keterampilan proses sains, yaitu peneliti mempersiapkan silabus, Rencana Pelaksanaan Pembelajaran (RPP), 
Lembar Kerja Siswa (LKS) serta lembar observasi aktivitas guru dan lembar observasi aktivitas siswa yang mengacu pada acuan utama pembelajaran dengan menggunakan metode eksperimen.

2.Tahap pelaksanaan pembelajaran keterampilan proses sains yang ditempuh dengan langkah-langkah metode eksperimen, yaitu (a) memperisapkan alat dan bahan yang dibutuhkan dalam eksperimen, (b) mempersiapkan Lembar Kerja Siswa, (c) menjelaskan kepada siswa tujuan eksperimen supaya siswa memahami masalah yang akan dibuktikan melalui eksperimen, (d) membantu, membimbing dan mengawasi eksperimen yang dilakukan siswa, (e) mendiskusikan hasil dan hambatan eksperimen.

Dapat disimpulkan bahwa penerapan metode eksperimen dapat meningkatkan keterampilan proses sains siswa. Peningkatan keterampilan proses sains siswa pada penelitian ini ditunjukan dengan meningkatnya persentase keterampilan proses sains siswa. Pada pra tindakan sebesar $35,71 \%$ atau 5 siswa, siklus I persentase keterampilan proses sains sebesar $69,23 \%$ atau 9 siswa mendapat skor minimal baik, sedangkan pada siklus II menjadi 84,61\% atau 11 siswa mendapat skor minimal baik. Terjadi peningkatan persentase keterampilan proses sains dari pra tindakan ke siklus I sebesar 33,52\%, siklus I ke siklus II sebesar 15,38\%. Penggunaan metode eksperimen pada siklus II persentase keberhasilannya mencapai $>80 \%$ sehingga proses pembelajaran sudah dikatakan berhasil.

\section{DAFTAR PUSTAKA}

Agustiningsih. (2014). Peningkatan Aktivitas dan Hasil Pembelajaran IPA Sekolah Dasar Melalui Metode Eksperimen. Jurnal Pedagogi Vol.1 No.1, 47-55.

Indarti, Y. (2016). Peningkatan Keterampilan Mengukur Melalui
Penerapan Metode Eksperimen

Pembelajaran IPA Sekolah

Dasar. Jurnal Pendidikan Guru

Sekolah Dasar, 361-371.

Juhji. (2016). Pembelajaran Sains Pada Anak RHUDATFUL ATHFAL. Jurnal Pendidikan Guru Rhudatful Athfal Vol. 1 No. 1, 49-59.

Kolin. (2014). Penerapan Pendekatan

Keterampilan Proses Untuk Meningkatkan Hasil Belajar Siswa. Jurnal Elektronik Pendidikan Matematika Tadulako Vol. 02 No. 02, 158-167.

Mulyani. (2015). Penggunaan Metode Eksperimen untuk Meningkatkan Hasil Belajar Rangkaian Listrik IPA Sekolah Dasar. Jurnal Pendidikan Profesional Vol 4(3), 45-54.

Nur Aeni, A. (2017). Meningkatkan Keterampilan Proses Sains Siswa Pada Materi Sifat-Sifat Cahaya Melalui Pembelajaran Inkuiri. Jurnal Pendidikan Ilmiah Vol. 2 No. 1, 71-83.

Pebriana, PH, dkk. (2019). Penerapan Model example Non Example Untuk Meningkatkan Keterampilan Proses Sains SD. Jurnal On Teacher Education Vol 1(1), 104-116.

Siregar, T. (2017). Meningkatkan Hasil Belajar Siswa Pada Mata Pelajaran IPA Menggunakan Metode Eksperimen. SEJ Vol. 7 No. 1, 1834.

Turdjai, dkk. (2017). Penerapan Metode Eksperimen Untuk Meningkatkan Sikap Ilmiah Dan Prestasi Belajar Siswa. Jurnal Ilmiah Teknologi Pendidikan Vol. 7 No. 2, 132-140.

Usman, S. (2011). Pembelajaran IPA di Sekolah Dasar. Jakarta: PT Indeks. 